\title{
希勫法による超高強度コンクリートの塩化物イオン濃度試験に関する研究 STUDY ON THE DILUTION METHOD FOR MEASUREMENT OF CHLORIDE CONCENTRATION IN FRESH CONCRETE WITH LOW WATER BINDER RATIO
}

\author{
寺内 利恵子*，早川光敬**，小山善行***，陣内 浩***，黒岩秀介***** \\ Rieko TERAUCHI, Mitsutaka HAYAKAWA, Yoshiyuki KOYAMA, \\ Hiroshi JINNAI and Shusuke KUROIWA
}

\begin{abstract}
Using bleeding water gathered by pressurized and filtered of diluted concrete sample with purified water, some methods were suitable to test for chloride concentration in water of fresh concrete with low-water binder ratio and with few bleeding water. As a result, the following conclusions were obtained. 1) In case of high-strength concrete, which $\mathrm{W} / \mathrm{B}$ is $16 \%$ and $18 \%$, using diluted concrete sample by purified water $50 \mathrm{cc}$ against fresh concrete $3 \mathrm{~kg}$, it is possible to test in about 15 minutes for chloride concentration in water of fresh concrete with low-water binder ratio. 2) It is preferable to gather a quantity of filtered water necessary for examine within 4 hours, while the change of density is small. 3) Among the methods by JASS5T-502, Coulometric titration and Mohr's method may have applicability to test for chloride concentration in water of fresh concrete with low water binder ratio, with dilution method. It is possible to examine for chloride concentration in water of fresh concrete with low water binder ratio at the construction site.
\end{abstract}

Keywords : High strength concrete, Chloride quantity, Coulometric titration, Mohr's method, Ion chromatographic analysis 高強度コンクリート，塩化物量，電量滴定法，モール法，イオンクロマトグラフ分析

\section{1.はじめに}

近年, 高層建築物が増加するなか, 設計基準強度 (以下, $\mathrm{Fc}$ と記 す) $100 \mathrm{~N} / \mathrm{mm}^{2}$ 以上の高強度コンクリートについて, 実用化に向けた 研究開発例えば1) が進められた。現在では, Fc150N/ $\mathrm{mm}^{2}$ として, 水結 合材比 (以下, W/B と記す) $16 \%$ の極めて低い W/B のコンクリート が実施工された報告がある2）。

一方，海砂に対する塩化物量の規制が始まった頃より，それまで 一般に化学的な滴定法により分析していた細骨材, 特に海砂中の塩 化物量を簡便な方法で測定できる機器の開発が始められた ${ }^{3)}$ １0)。 昭和 61 年 6 月 2 日には建築指導課長通達においてコンクリート中の 塩化物の総量が規制 11 )され，原則として，工事現場において打迈 み前のフレッシュコンクリートについて塩化物量の測定を行うこと になっている。しかしながら, W/B が $20 \%$ を下回るような高強度コ ンクリートは，ブリーディング量が少なく, 塩化物量の測定に必要 なろ液などの採取に時間のかかる場合や困難な場合が多く，迅速に 塩化物量を測定する方法がないのが現状である。

そこで本論では, W/B が $20 \%$ を回るような高強度コンクリート について，フレッシュコンクリートを純水で希釈した試料を加圧ろ 過した測定用試料により，コンクリート中の水に含まれる塩化物イ オン濃度を簡便に測定する手法を検討した。

* 大成建設(侏)建築本部 主任

** 東京工芸大学工学部建築学科 教授 · 博士 (工学)

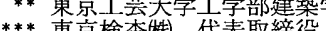

**** 大成建設株技術センター 主任研究員 $\cdot$ 博士 (工学)

***** 大成建設株技術センター 主任研究貝・工修

\section{2. 陚験方法について}

フレッシュコンクリートを純水で希䣋した試料を加圧ろ過した 測定用試料による塩化物イオン濃度の測定について, 以下にその具 体的な手順を述べる。

希釈コンクリート試料は，ステンレス製の円筒形の容器を用いフ レッシュコンクリートと純水をそれぞれ規定量計量した後，ステン レス製の薬さじを用いてコンクリートが均質に希釈されるように摚 挷して作製した。

測定用試料は, 希釈コンクリートのモルタル部分を加圧ろ過器用 の容器に移して穴開き加圧板とモルタルの間にろ紙をはさんだ状態 で加圧し，加圧板の穴から浮き出たブリーディング水とした。この ブリーディング水の塩化物イオン濃度測定値に対して, 希釈前の塩 化物イオン濃度に補正するための係数を，調合計画値より補正する 式（1）より求めた。

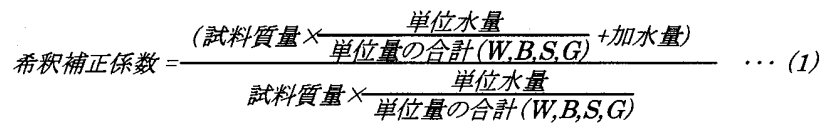

フレッシュコンクリートの計量, 加える純水の計量・擋找, 加圧 ろ過およびろ液採取などの一連の作業は, 室温 $20 \pm 2{ }^{\circ} \mathrm{C}$, 湿度 $60 \pm$ $5 \%$ の室内で行い，コンクリート製造後 15 分程度で加圧を開始する
Assistant Manager, Building Construction Div., Taisei Corp.

Prof., Dept. of Architecture, Faculty of Eng., Tokyo Polytechnic Univ., Dr. Eng. President, Tokyo Kensa Co., Ltd.

Senior Research Engineer, Technology Center, Taisei Corp., Dr. Eng.

Senior Research Engineer, Technology Center, Taisei Corp., M. Eng. 
ことを基本とした。

図1に使用したろ過器を示す。ステンレス製の容器に移したコン クリート試料のモルタル部分を加圧し，プラスチック製加圧板に開 けられた直径 $2 \mathrm{~mm}$ の孔から浮き出たブリーディング水を塩化物イオ ン測定用の試料とした。希釈前のコンクリート試料は, 粗骨材が加 圧に影響することを防ぐため, 約 0.25 师ルの試料を加圧することと した。一方, 希釈後のコンクリート試料は液状で, 希釈前と同量の 試料を容器に入れた場合に加圧作業が困難であったことから, 事前 検討をもとに，ある程度のブリーディング水が上がると考えられた 約 0.03 リ㤶ルの試料を加圧することとした。加圧は手動で, 加圧ハン ドルを閉め込んだ。

\section{3. 希釈法によるろ液の抽出に閏する基本検討}

ここでは, まずW/Bが 20\%を下回るような高強度コンクリートを 希釈して得られたろ液を用いて, 塩化物イオン濃度を測定すること の妥当性について検討した。

検討に用いたコンクリートの使用材料を表 1 に, 調合を表 2 に示 す。これらは, 文献 2）に示される超高層 RC 造住宅の建設工事にお いて, 実施工に利用された $\mathrm{Fc} 150 \mathrm{~N} / \mathrm{mm}^{2}$ と $\mathrm{Fc} 130 \mathrm{~N} / \mathrm{mm}^{2}$ のコンクリート を忠実に再現したものである。セメントには, 普通ポルトランドセ メント, スラグせっこう系混和材 ${ }^{12)}$ およびシリカフュームを $7: 2$ : 1 の割合でプレミックスした特殊結合材を使用した。骨材には安山 岩系砕石・砕砂を使用した。化学混和剂にはポリカルボン酸系の高 性能隇水剤と, 低級アルコール系の収縮低隇剤を使用した。

コンクリートのW/B はFc150を目標とした $16 \%$ と F 130 を目標と した $18 \%$ の 2 種類とした。いずれも単位水量は $150 \mathrm{~kg} / \mathrm{m}^{3}$ とした。

\section{1 希釈によるろ液抽出時間の短維効果}

ここでは, 希釈によるろ液の抽出時間の短縮効果を確認するため, 加える純水の量を変動要因とした加圧ろ過器 1 つあたりのろ液量の 経時変化を測定した。目標とするろ液の採取量は, 後の実験で用い る測定器での最低必要量を満足する $1 \mathrm{cc}$ 程度とした。なお, 加圧は 手動で行うため, ここでの評価は, 同一の試験者が加圧ろ過器を使 用した場合の相対評価となる。

測定に使用するコンクリートは W/B=16\%のものとした。希釈水を 加えるコンクリートの量は $3 \mathrm{~kg}$ とし, これに, $25 \mathrm{cc}, 50 \mathrm{cc}$ および $100 \mathrm{cc}$ の 3 水準の純水を加えることとした。希釈後のコンクリートの W/B は, 純水 $25 \mathrm{cc}$ を加えた場合が $18.2 \%$, 純水 $50 \mathrm{cc}$ を加えた場合が $20.4 \%$ ，純水 $100 \mathrm{~g}$ を加えた場合が $24.7 \%$ となる。

図 2 に加圧後の経過時間と採取したろ液量の関係を示す。今回の 実験条件では, 希釈前のコンクリートに対し, 純水 $50 \mathrm{cc}$ を加えた場 合 (W/B=20.4\%) は約 2 倍, 純水 $100 \mathrm{cc}$ を加えた場合（W/B=24.7\%） は約 3 倍のろ液が得られた。しかし, 純水 $25 \mathrm{cc}$ を加えた場合は, 今 回用いた加圧方法では効率的なろ液の採取が難しかった。また，目 標の $1 \mathrm{cc}$ 程度のろ液を得る時間は, 希釈前のコンクリートが 60 分で あったのに対し, 純水 $50 \mathrm{cc}$ もしくは $100 \mathrm{cc}$ を加えた場合は 15 分以 内に短縮できた。これより, 加える純水の量が多くなれば, 加圧後 の早い時間帯で測定に必要なろ液を得ることができるといえる。

筆者らの経験では, W/B=20\%程度で製造される Fc100 クラスのコ ンクリートでは,万液の抽出が困難となることはない。したがって, 希釈後のW/B $20 \%$ 以上とすれば, 問題なくろ液が抽出できると考
えられる。ただし, 必要以上に希釈を行えばろ液中の塩化物イオン 量が少なくなり，試験方法によっては塩化物イオンを検知できなく なる恐れがあるため, 本論の範囲においては, 加える純水の量は, コンクリート $3 \mathrm{~kg}$ に対して $50 \mathrm{cc}$ 程度が理想的であると判断した。ま た, 本研究では希釈前コンクリートと希釈後のコンクリートの比較 検討を行うため, 測定用試料の採取時間は, 希釈前のコンクリート でも $1 \mathrm{cc}$ のろ液が採取可能であった加圧後 1 時間を基本として検討 を進めることとした。

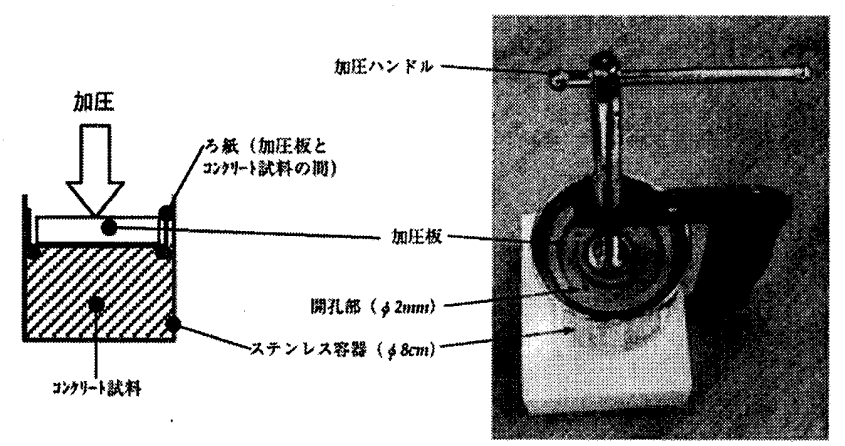

図 1 加圧万過器

表 1 使用材料

\begin{tabular}{|c|c|}
\hline 結合材 & $\begin{array}{l}\text { 高強度結合材（普通ポルトランドセメント：スラグ } \\
\text { せっこう系混和材：シリカフューム=7:2:1) }\end{array}$ \\
\hline 細骨材 & $\begin{array}{l}\text { 大月産安山岩砕砂 } \\
\text { (表乾密度 } 2.60 \mathrm{~g} / \mathrm{cm}^{3}, \text { 吸水率 } 2.41 \sim 2.74 \% \text { ) }\end{array}$ \\
\hline 粗骨材 & $\begin{array}{l}\text { 大月産安山岩砕石 } 2005 \\
\text { (表乾密度 } 2.60 \mathrm{~g} / \mathrm{cm}^{3} \text {, 吸水率 } 1.84 \sim 2.58 \% \text { ) }\end{array}$ \\
\hline 混和剤(1) & 収縮低滅剂（低級アルコール系） \\
\hline 混和剤(2) & 高性能減水剤（ポリカルボン酸系） \\
\hline 練混ぜ水 & 上水道水以外の水 (地下水) \\
\hline
\end{tabular}

表 2 調合計画

\begin{tabular}{|c|c|c|c|c|c|c|c|}
\hline \multirow{2}{*}{$\begin{array}{c}\text { 目標 Fc } \\
\left(\mathrm{N} / \mathrm{mm}^{2}\right)\end{array}$} & \multirow{2}{*}{$\begin{array}{c}\text { W/B } \\
(\%)\end{array}$} & \multicolumn{5}{|c|}{ 単位量 $\left(\mathrm{kg} / \mathrm{m}^{3}\right)$} & \multirow{2}{*}{$\begin{array}{c}\text { 混和珮(2) } \\
\text { Ad/B } \\
(\%)\end{array}$} \\
\hline & & $\begin{array}{l}\text { 結合 } \\
\text { 材 B } \\
\end{array}$ & $\begin{array}{l}\text { 水 } \\
\mathrm{W}\end{array}$ & $\begin{array}{r}\text { 細骨 } \\
\text { 材 S } \\
\end{array}$ & $\begin{array}{l}\text { 粗骨 } \\
\text { 材 G } \\
\end{array}$ & $\begin{array}{l}\text { 混和 } \\
\text { 剂(1) } \\
\end{array}$ & \\
\hline 150 & 16 & 938 & 150 & 550 & 817 & 7 & $2.0 \sim 3.0$ \\
\hline 130 & 18 & 834 & 150 & 642 & 817 & - & 3.0 \\
\hline
\end{tabular}

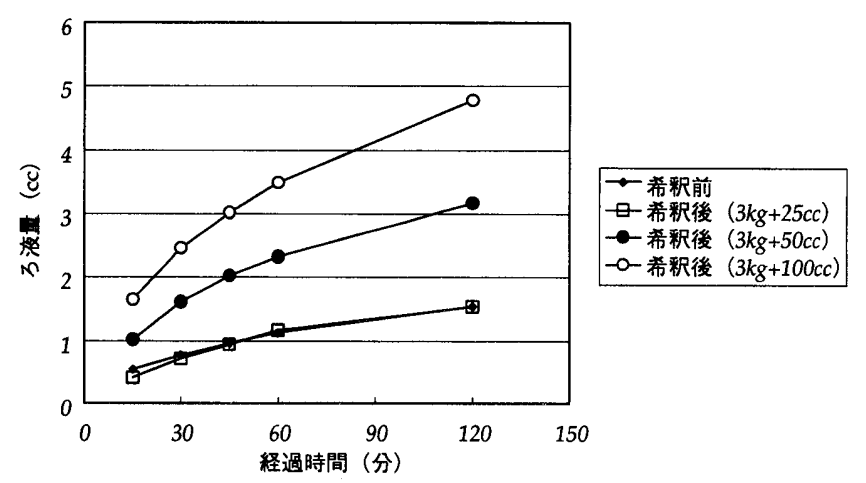

因 2 万液測定結果

\section{2 万液の採取時期と塩化物イオン量の関保}

コンクリートの塩化物量と注水からの時間経過の関係は, 5 時間 後まで変化がないとされる報告 ${ }^{13)}$ と, 注水 1 時間以内にすでにフ リーデル氏塩の固定が始まり，測定值が変わるという報告 14)や15) がある。前節の結果より，本論では加圧後 1 時間でのろ液採取を行 
うこととしたが,ここではその妥当性を実験的に検討しておくこと とした。検討実験では，W/B=16\%のコンクリートを準備し，1時間 後, 2 時間後, 3 時間後, 4 時間後, および 5 時間後にろ液の採取を 行い，塩化物イオン濃度の測定を行った。測定による誤差を小さく するため，測定方法は，JISA 1144 に規定されているイオンクロマ トグラフ法とした。

図 3 にろ液採取時期による塩化物量の変化を示す。縦軸は，測定 值に計画単位水量を乗じて求めた塩化物量とした。万液の塩化物量 は,加圧より 1 4 時間までの範囲であれば比較的安定した傾向にあ ったが，それを超えると希採前コンクリートの塩化物量が減少した。 その理由は，測定誤差，万液の乾燥による濃度変化などが考えられ るが, 明確ではない。図中には JIS A 1154 によって測定した硬化後 のコンクリートの全塩分測定結果も示した。これと比べても加圧後 4 時間までは希积前後を問わず安定した測定結果が得られると考え られる。

\section{3 加える純水の量の検討}

コンクリートを希釈する場合，測定值は希釈後のコンクリートの 均質性などが影響することになる。特に，希釈水が少ない場合には， 摚找作業も困難であり，希釈後のコンクリートの均質性に疑問が残 る。そこで，ここでは同一のフレッシュコンクリートから同じ作業 によって 7 つ希秋後のコンクリートを作製し，これらの塩化物イ オン量測定值の変動を調べることとした。前節と同様に, 希釈水を 加えるコンクリートの量は $3 \mathrm{~kg}$ とし,これに, $25 \mathrm{cc}, 50 \mathrm{cc}$ および $100 \mathrm{cc}$ の 3 水準の純水を加えることとした。測定による誤差を小さくする ため, 塩化物イオン量の測定方法は, JISA 1144 に規定されている イオンクロマトグラフ法とした。

図 4 に試験結果を示す。縦軸は, 測定値に計画単位水量を乗じて 求めた塩化物量とした。希积前のコンクリートから採取したろ液中 の塩化物量の変動係数は $2.8 \%$ 程度であった。これに対し， $50 \mathrm{cc}$ お よび 100 cc の純水を加えたコンクリートの塩化物量測定結果の変動 係数は希釈前とほほ同様の $2.2 \sim 2.5 \%$ 程度であった。一方, $25 \mathrm{cc}$ の純水を加えたコンクリートでは，変動係数が $8.9 \%$ 程度とややば らつきが大きくなった。この結果より，十分な希釈水を加えて擋抖 を行えば，希釈後のコンクリートは均質になるものと考元られる。

\section{4 試料とするコンクリートの量の検討}

JIS A 1115 (フレッシュコンクリートの試料採取方法) によれば, コンクリートの試料の採取は20リットル以上と規定されている。し かし,一般の工事現場で 20 リットル以上のフレッシュコンクリート に純水を加えて均質になるまで擋找するのは容易ではない。本論で 用いたコンクリートの単位容積質量が $2.4 \sim 2.5 \mathrm{~kg} / 川$ 师であること を考えれば，20 リットルのコンクリートを攪汼するということは， 質量にして $50 \mathrm{~kg}$ 程度のコンクリートを擋拌することになる。

そこで，試料とするコンクリートの量を隇らした場合の測定誤差 を検討し，試料の量を検討することとした。ここでは，試料とする コンクリートの量を $0.6 \mathrm{~kg}, 3 \mathrm{~kg}, 6 \mathrm{~kg}$ の 3 水準とし, 同一のフレッ シュコンクリートから同じ作業によって7つの希釈後のコンクリー 卜を作製し，これらの塩化物イオン量測定值の変動を調べた。加え

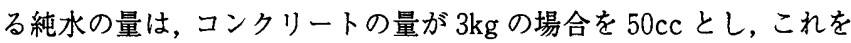
基本として, 試料の量と希积水の質量比が等しくなるように, $0.6 \mathrm{~kg}$ の場合は $10 \mathrm{cc} ， 6 \mathrm{~kg}$ の場合は $100 \mathrm{cc}$ とした。

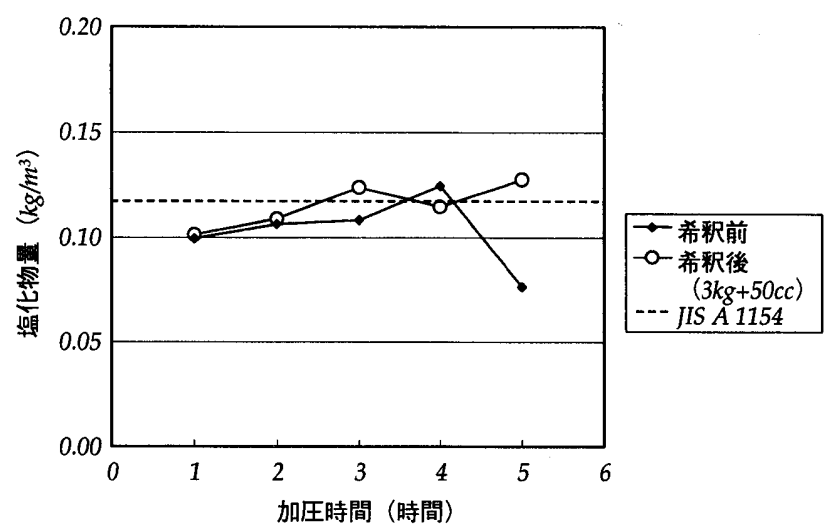

図 3 万液抽出時期による塩化物量の変化

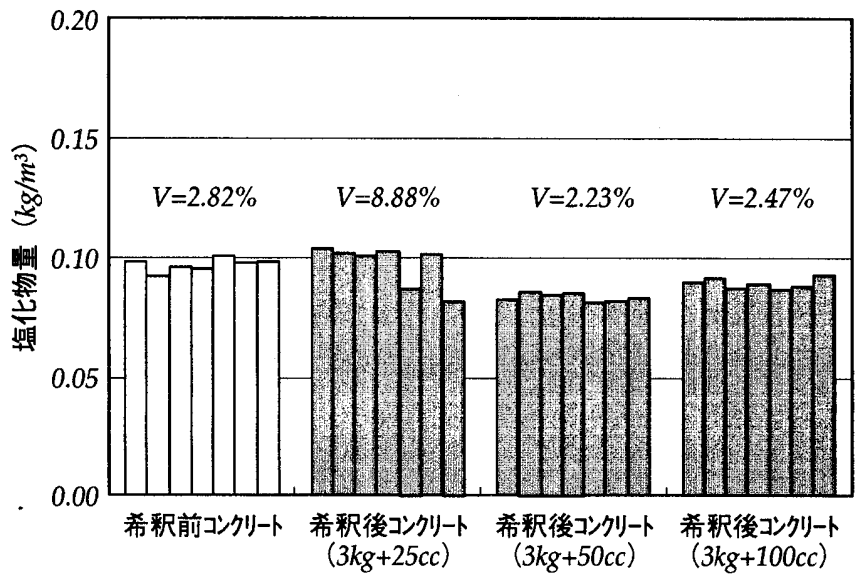

図 4 加えた純水の量を変動要因とした試験結果

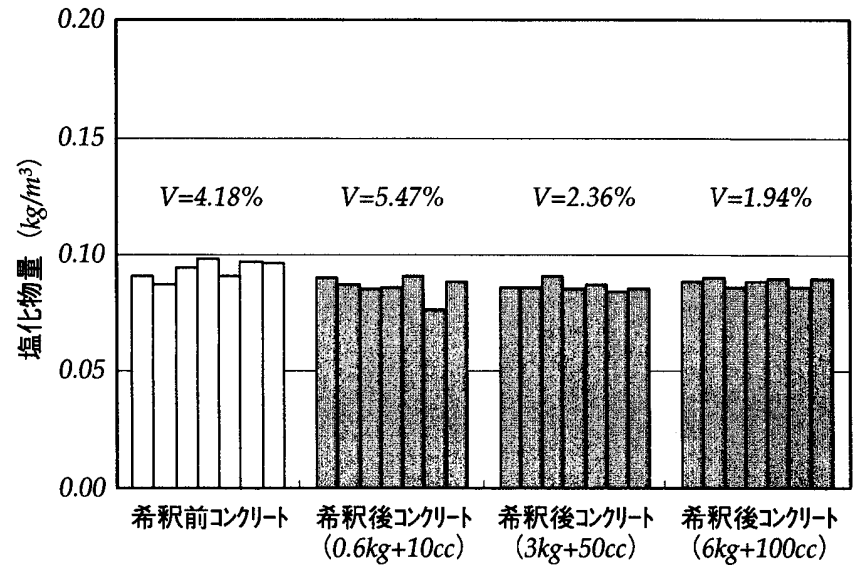

図 5 フレッシュコンクリート量を変動要因とした試験結果

因 5 に試験結果を示す。縦軸は，測定値に計画単位水量を乗じて 求めた塩化物量とした。希釈前のコンクリートから採取したろ液中 の塩化物量測定結果の変動保数は $4.2 \%$ 程度であった。これに対し， 試料を $3 \mathrm{~kg}$ および $6 \mathrm{~kg}$ とした場合のコンクリートの塩化物量測定結 果の変動係数はこれを下回るものであった。したがって，最低 $3 \mathrm{~kg}$ 程度の試料を用いれば，希积後のコンクリートは均質になるものと 考えられる。

試料の量による試験結果がばらつく原因のひとつにフレッシュ コンクリート採取時点での試料中のセメントペースト分量の差が考 えられることから，測定に用いた試料から粗骨材を洗い出し，その 絶乾質量を比較した。 
表 3 に洗い出した粗骨材の絶乾質量を示す。試料の量に関わらず 変動係数は 3〜 5\%程度であり, 当初予想した採取量が少ない試料で の粗骨材量のばらつきは見られなかった。このことから, 前述の実 験時に採取したコンクリート試料中のセメントペースト量は，ほほ 一定であったと言える。試料が $0.6 \mathrm{~kg}$ の場合の試験結果がばらつく 理由は, 計量誤差や試料中の水の絶対量が少なくブリーディング水 が出にくいことなどの影響と考えられる。

\section{JASS5T-502 の希釈法への適用}

フレッシュコンクリート中の水の塩化物イオン濃度試験方法は JIS A 1144 で規格化されているが, この方法は特殊な分析機器や測 定能力が必要とされるため, 工事現場での適用は難しい。したがっ て, ほとんどの工事で, 日本建築学会の JASS5T-502 フレッシュコン クリート中の塩化物量の簡易試験方法（以下, JASS5T-502 と記す） による塩化物量の測定が行われている。

JASS5T-502 で用いる塩化物量測定器には, 精度, 再現性, 取り扱 いの簡便性および通常の使用に対する耐久性などについて公的な機 関の評価を受けた 15 の測定器があるとされる。ここでは, 一般的に 使用されることが多い表 4 に示す 4 種類の測定原理の異なる測定器 について基礎的傾向を把握し，実施工時に使用する機器を選定する こととした。

\section{1 既知の襄度の $\mathrm{NaCl}$ 溶液による基硞実験}

まず, 測定器 $\mathrm{A} \sim \mathrm{D}$ 用いて既知の濃度の $\mathrm{NaCl}$ 溶液中に含まれる塩 化物イオン濃度を測定し，その結果を比較した。なお，全ての測定 器は（財）国土開発技術センターの技術評価を取得しており，測定 範囲はコンクリートの塩化物総量規制で設定された值 $0.30 \mathrm{~kg} / \mathrm{m}^{3}$ お よび $0.60 \mathrm{~kg} / \mathrm{m}^{3}$ を考虑した $0.05 \sim 0.5 \%\left(\mathrm{Cl}^{-} /\right.$water $)$である。 $\mathrm{W} / \mathrm{B}=20 \%$ 以下の高強度コンクリートを測定対象とした場合, $\mathrm{Cl}$-濃 度領域は $0.1 \%$ 前後と考えられるため, 測定用試料は, $\mathrm{NaCl} 0.1 \mathrm{~mol}$ 溶液（Cl-濃度 $0.354 \%), \mathrm{NaCl} 0.01 \mathrm{~mol}$ 溶液（ $\mathrm{Cl}^{-}$濃度 $0.0354 \% ）$ および $\mathrm{NaCl} 10.1 \mathrm{~mol}$ 溶液を純水で 2 倍希釈した溶液 $\left(\mathrm{Cl}^{-}\right.$濃度 $0.177 \%)$ の 3 種類とした。

図 6 に測定結果を示す。Cl一濃度が低い $\mathrm{NaCl} 0.01 \mathrm{~mol}$ 溶液につい ては, 全ての測定器がそれぞれ設定した $\mathrm{Cl}^{-}$濃度に近い值を測定值 として示した。しかし, $\mathrm{Cl}$-濃度が高くなるにつれ, 測定器 C（イオ ン電極法）および D（電極電流測定法）は設定した Cl-濃度に対し て $1.2 \sim 1.5$ 倍大きい測定値を示した。一方, 測定器ごとの傾向から， 測定器 $\mathrm{A}$ (電量滴定法) が $\mathrm{Cl}$ 一濃度にかかわらず, 測定用試料に対 し設定した值とほほ同じ測定值を示し，誤差のない測定ができると いえる。また, 測定器 B (モール法) は設定濃度の 1.1 倍程度の測 定值を示した。機器の測定誤差を考慮すると実務上も問題なく使用 できると考えられる。測定器 C (電極電流測定法) および測定器 D (イオン電極法) は1.2 1.5 倍の測定值を示し, $\mathrm{Cl}$ 一濃度が高い場 合, 測定値がやや高め示される傾向にあった。本実験では, 測定器 A（電量滴定法）および測定器 B（モール法）を使用するのが望まし いという結果が得られたが、各測定器は所定のキャリブレーション を行っており，本来はばらつきの少ない測定值が得られると考えら れることから, 本論では各測定器の測定值に表 4 に示す機器補正係 数を乗じ，その値を試験值とすることとした。
表 3 洗い出した粗骨材の絶乾質量（単位：g）

\begin{tabular}{c|c|c|c}
\hline 陚料の量 & $0.6 \mathrm{~kg}+10 \mathrm{cc}$ & $3 \mathrm{~kg}+50 \mathrm{cc}$ & $6 \mathrm{~kg}+100 \mathrm{cc}$ \\
\hline \hline 1 & 233.2 & 976.3 & 2001.8 \\
\hline 2 & 219.7 & 941.9 & 1735.2 \\
\hline 3 & 214.1 & 886.2 & 1859.1 \\
\hline 4 & 227.4 & 924.8 & 1874.2 \\
\hline 5 & 229.6 & 935.4 & 1899.3 \\
\hline 6 & 219.8 & 903.8 & 2008.8 \\
\hline 7 & 205.5 & 936.5 & 1899.7 \\
\hline 平均 $(\mathrm{g})$ & 221.3 & 929.3 & 1896.9 \\
\hline$\sigma(\mathrm{g})$ & 9.61 & 28.8 & 92.8 \\
\hline 変動係数 $(\%)$ & 4.34 & 3.10 & 4.89 \\
\hline
\end{tabular}

表 4 測定原理と機器補正係数

\begin{tabular}{c|c|c}
\hline 機器 No. & 測定原理 & 機器補正係数 \\
\hline \hline 測定器 $\mathrm{A}$ & 電量滴定法 & 1 \\
\hline 測定器 $\mathrm{B}$ & モール法 & 0.9022 \\
\hline 測定器 C & 電極電流測定法 & 0.6985 \\
\hline 測定器 D & イオン電極法 & 0.6437 \\
\hline
\end{tabular}

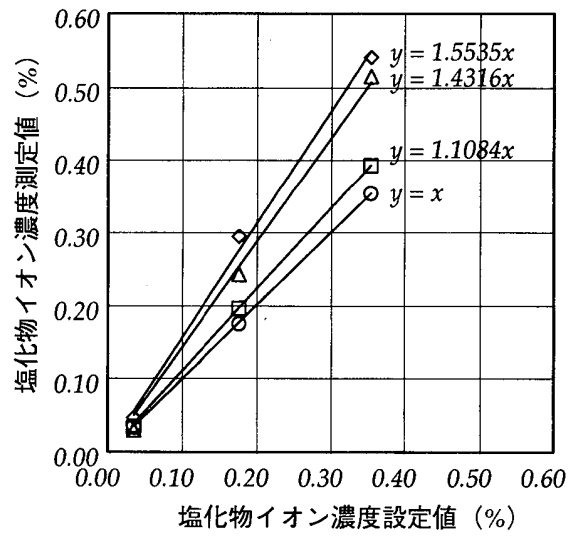

\begin{tabular}{|l|}
\hline 0 電量滴定法 \\
$\square$ モール法 \\
$\Delta$ 電極電流測定法 \\
$\diamond$ イオン電極法
\end{tabular}

図 6 ，既知の濃度の $\mathrm{NaCl}$ 溶液の塩化物イオン濃度測定結果

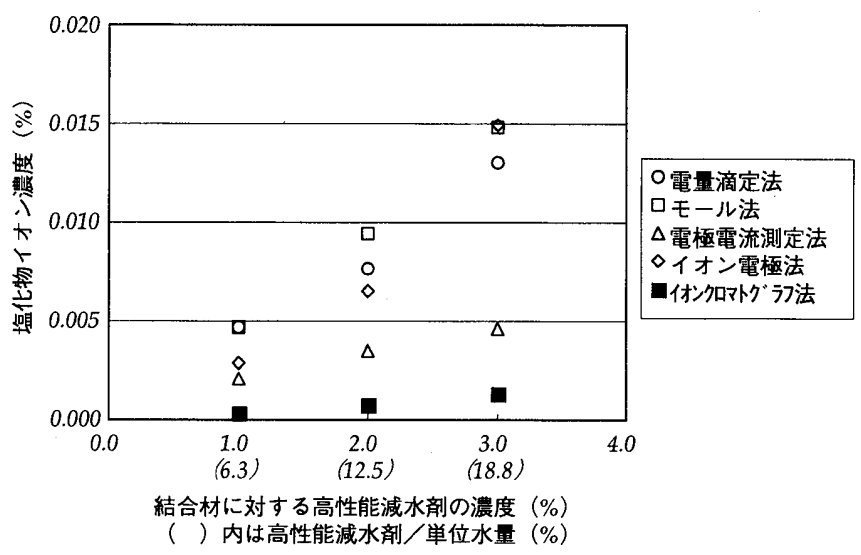

図 7 希釈した高性能減水剤の塩化物イオン濃度測定結果 


\section{2 高性能減水剂の影譥}

JASS5T-502 で用いる塩化物量測定器の中には, $\mathrm{Br}^{-}$や I-などの妨 害イオンを $\mathrm{Cl}$-として測定してしまう機器がある可能性もある ${ }^{4)}$ 。 また，筆者らは，あらかじめイオンクロマトグラフによる分析によ り $\mathrm{W} / \mathrm{B}=16 \%$ の高強度コンクリートで使用する高性能減水剂に微量 の $\mathrm{Br}^{-}$が入っていることを確認した。そこで, 高性能減水剤の $\mathrm{Cl}^{-}$ 濃度を測定し, 測定器ごとの試験值を比較した。測定用試料は, 実 際の調合範囲を想定して, 結合材に対する高性能減水剤の濃度とし て $1 \% ， 2 \%$ および $3 \%$ の 3 種類とした。

図 7 に高性能減水剤の塩化物イオン濃度測定結果を示す。高性能 減水剤の濃度が高くなるほど各測定器により測定值が大きく異なっ た。特に測定器 D（イオン電極法）は対数的に測定值が上昇してい ることから，4．1で得られた結果と合わせると妨害イオンを塩化 物として計測している可能性があると考えられる。4．1で高い測 定値を示した測定器 C（電極電流測定法）であるが,ここでは低い 測定值を示した。この結果より, 測定器 D (イオン電極法) は使用 せず, 測定器 A（電量滴定法), 測定器 B (モール法) および測定器 C（電極電流測定法）を用いて研究を進めることとした。

\section{3 各測定器を用いて測定した坦化物量の比較}

ここでは，JIS A 1144 のイオンクロマトグラフ法を用いて測定し たフレッシュコンクリート中の塩化物量と, 表 4 に示した各測定器 を用いて測定したフレッシュコンクリート中の塩化物量の比較を行 った。測定では, 同じ材料を用いて同じ調合のコンクリートを 5 回 練混ぜ，それぞれについて，各測定器によるフレッシュコンクリー ト中の塩化物イオン量を測定した。比較対象は W/B $=16 \%$ おび W/B $=18 \%$ の 2 調合とした。

図 8 に各測定值の比較結果を示す。いずれの水結合材比において も, 測定器 $\mathrm{A}$ (電量滴定法) および測定器 $\mathrm{B}$ (モール法) の 2 種類は 概ね JIS A 1144 のイオンクロマトグラフ法と同等かやや高い值を示 したが, 測定器 C（電極電流測定法）は明らかに低い值を示した。 そこで,ここでの結果に，4．1および4.2の結果も考虑し，以 降は測定器 $\mathrm{A}$ (電量滴定法) および測定器 $\mathrm{B}$ (モール法) の 2 種類で 検討を進めることとした。

\section{5. 実施工のコンクリートを用いた希釈法の妥当性の検証}

希釈コンクリートから加圧ろ過したろ液について, 塩化物量測定 用の試料としての妥当性を明らかにするため，同じアジテータトラ ックから採取した希釈前のコンクリートと希釈後のコンクリートに ついて，抽出したろ液の試験結果を比較検討した。

表 5 に実施工時の試験項目を示す。試料は, 希橎前のフレッシュ コンクリートとフレッシュコンクリート $3 \mathrm{~kg}$ に対し純水を $50 \mathrm{~g}$ 加え て擋汼した希哷後のコンクリートの 2 種類とし, それぞれ加圧ろ過 して抽出したろ液を用いた。測定方法は, JASS5T-502 の電量滴定法 およびモール法とした。さらに, JIS A 1154 により硬化コンクリー トの全塩分量も測定した。測定したアジテータトラック数は, W/B=16\%は 60 台，W/B=18\%は 30 台である。フレッシュコンクリー トの計量, 加える純水の計量・擋挥, 加圧ろ過およびろ液採取など の一連の作業は, これまでの測定と同様に室温 $20 \pm 2^{\circ} \mathrm{C}$, 湿度 $60 \pm$ $5 \% の$ 室内で行い, 同一の試験者が試料作成㧍よび測定を行った。試 験結果を图 9 に示す。ここでは測定方法ごと，W/Bごとに結果をま
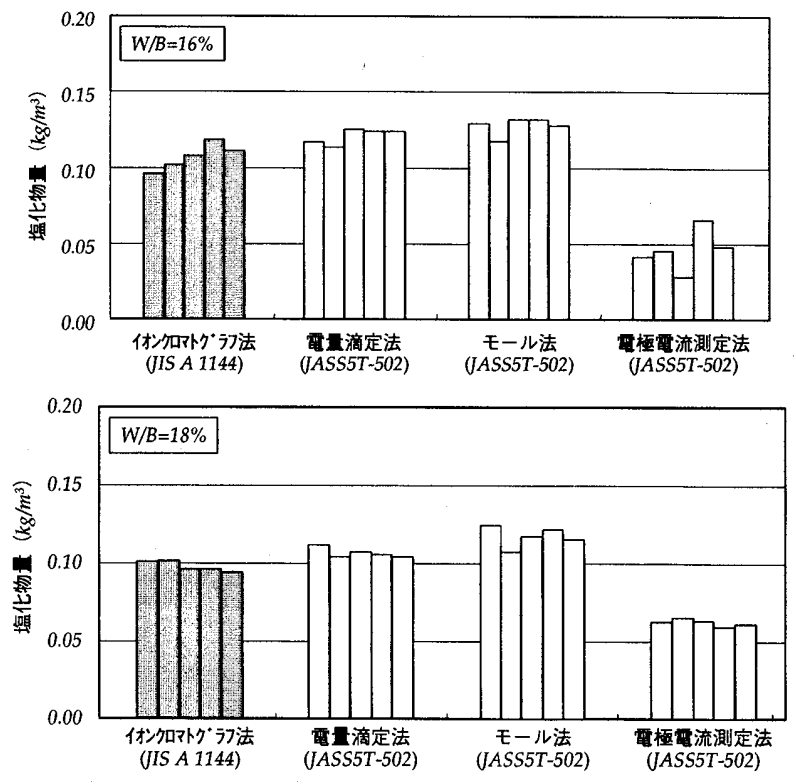

図 8 計算値と測定値の比較

表 5 実施工時の試験項目

\begin{tabular}{c|c}
\hline 塩化物量測定用試料 & 試験方法 \\
\hline \multirow{2}{*}{ 電量滴定法 } & 希瀵前のコンクリート \\
\cline { 2 - 2 } & 希瀵後のコンクリート \\
\hline \multirow{2}{*}{ モール法 } & 希釈前のコンクリート \\
\cline { 2 - 2 } & 希釈後のコンクリート \\
\hline
\end{tabular}
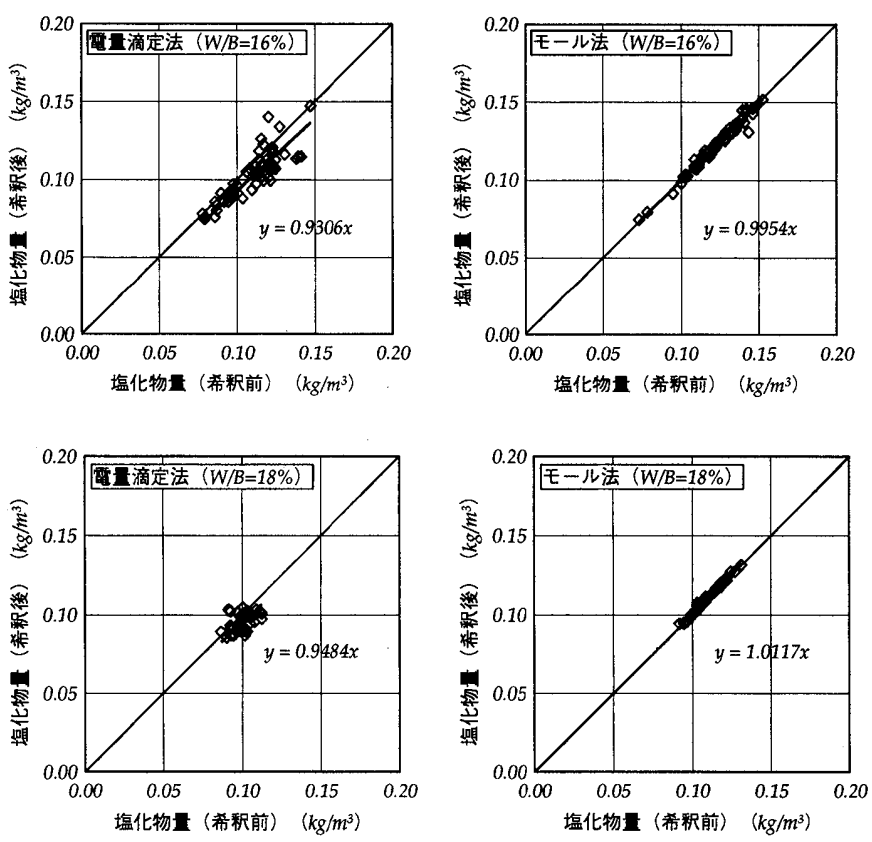

図 9 塩化物量（計画単位水量）

とめた。試験值は，希釈前のコンクリートと希釈後のコンクリート それぞれのろ液で測定した測定值に, 希釈補正係数わよび機器補正 係数を乗じた。塩化物量を求めるために乗ずる単位水量は, 計画単 位水量 $150 \mathrm{~kg} / \mathrm{m}^{3}$ 一律として求めた。

また, 塩化物量を求めるためにはフレッシュコンクリート中の水 の量を正確に求めておく必要があることから, 単位水量を実測単位 
水量で補正した試験值でも検討した。ここでの単位水量試験方法は, 水中質量法 16) とした。結果を図 10 に示す。出荷時の単位水量試 験結果が $150 \mathrm{~kg} / \mathrm{m}^{3}$ の目標值に対して平均值 $149.8 \mathrm{~kg} / \mathrm{m}^{3}$, 変動係数 $2 \%$ 程度と非常に安定しており,補正係数や塩化物量計算に用いる水 量を計画単位水量としても実測単位水量としてもほとんど変わらな い結果となった。

図 9 および図 10 より，希釈前後の試験結果は高い相関性が見ら れ，測定方法や水結合材比に関わらず原点回帰直線上に分布した。 これより，希釈コンクリートのブリーディング水を測定することで フレッシュコンクリートの塩化物量試験を行うことが可能と言える。
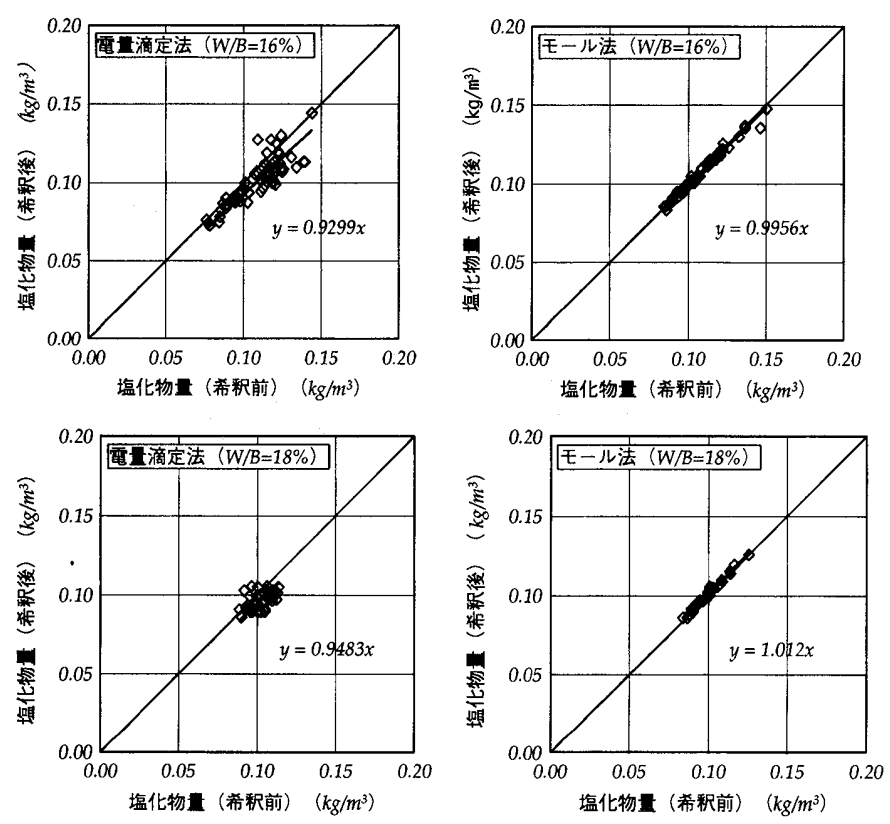

図 10 塩化物量（実測単位水量）

\section{6.まとめ}

水結合材比が $20 \%$ 下回るようなブリーディングの少ない高強 度コンクリートについて，フレッシュコンクリートを純水で希釈し た試料を加圧ろ過した測定用試料により，コンクリート中の水に含 まれる塩化物量を簡便に測定する手法を検討した結果，以下の結論 を得た。

1） $\mathrm{W} / \mathrm{B}=16 \%$ および $\mathrm{W} / \mathrm{B}=18 \%$ の高強度コンクリートの場合, フレッ シュコンクリート $3 \mathrm{~kg}$ に対して純水 W/B を $50 \mathrm{cc}$ 加えて加圧万過 することで, 15 分程度で塩化物量測定に必要なろ液を得られ迅速 に測定を行うことが可能である。

2）製造直後に加圧したフレッシュコンクリートについて，コンクリ 一ト試料加圧からろ液採取まで 4 時間以内であれば， 万液の塩化 物イオン濃度の変化が小さいと考えられる。

3）今回検討を行った JASS5T-502（フレッシュコンクリート中の塩 化物量の簡易試験方法）の測定方法のうち，電量滴定法とモール 法は低水結合材比の高強度コンクリートの希釈法による塩化物 量測定に適用できる可能性がある。他の方法の適用については今 後の検討による。工事現場に打いても，希积コンクリートを作製 することで塩化物イオン量を簡便に測定することが可能である。
謝 辞: 本研究にあたり,横浜デイ・エム生コン株式会社港北工場, 第一コンクリート株式会社川崎工場, 株式会社デイ・シイ，株式会 社ポゾリス物産, 太平洋マテリアル株式会社, 株式会社中研コンサ ルタント, 吉川産業株式会社, 東京工芸大学早川研究室の学生諸氏 などの皆様の多大なご協力をいただきました。ここで改めて本研究 に関わった方々に深謝いたします。

\section{参考文献}

1）小室 努・黑岩秀介・渡辺英義・陣内 浩： $150 \mathrm{~N} / \mathrm{mm}^{2}$ 級の超高強度コンク リートを用いたR C 柱の実用化研究, コンクリート工学, Vol39, №.10, pp. $9-16,2001.10$

2）陣内 浩・渡邉悟士 - 寺内利恵子 - 阿部剛士：設計基準強度 $150 \mathrm{~N} / \mathrm{mm}^{2}$ の 低収縮型高強度コンクリートの打設と品質管理，コンクリートテクノ， Vol. 25, No. $9,2006.9$

3）大橋雄二：コンクリート用細骨材の塩分について, 建築技術, №. 317, pp. 101-103, 1978.1

4）桝田佳寛：フレッシュコンクリートの塩化物含有量の試験方法, コンクリ 一下工学, Vol.25, №.2, pp. 26 32, 1987.2

5）小林明夫・長田晴道・児玉育雄：簡易な方法による海砂 生コン中の塩分 測定，セメント・コンクリート，No.456，pp. 29-33，1985.2

6) 山田明文・橋田長一：海砂およびコンクリート中の塩化物の測定方法一技 術の現状，電気化学，52，№.11，pp.728-733，1984

7) 蒔田 実·坂本浩行: 海砂および海砂使用コンクリート中の塩分の測定法, コンクリート・ジャーナル, Vol.12, No.10, pp47-52, 1974.10

8）笠井芳夫・金井和夫・小川良一郎：試験紙による生コンクリート中の塩化 物含有量判定方法, 日本建築学会学術講演梗概集（構造系), pp. 203-204, 1973. 10

9）小柳成男：体温計の要領で生コンや骨材中の塩分を測る，建築技術, pp. $94-97,1984.5$

10) 橋田長一:化学知識のいらない海砂中の塩分測定器, 建築技術, pp98-100, 1984.5

11）日本建築防災協会・日本建築センター：コンクリートの塩化物総量規制 及びアルカリ骨材反応対策講習会 資料, 1986

12）日本建築学会：高強度コンクリート施工指針（案）・同解説，2005.1

13）草野昌夫 ·渡辺夏也・村松良展：凝結硬化過程に打ける塩分挙動，七メ ント技術年報，42，pp. 375-378，1988

14）浜辺謙吉・瀬上光男：簡易塩化物測定器によるフレッシュコンクリート 中の塩化物量の測定例と誤計算に対する補正方法, 日曹マスタービルダー ズ研究所報, No. 8, pp. 78-81, 1988

15）平尾 宙・羽原俊祐・久米美穂子：セメントサスペンジョンに扔ける塩 化物イオンの挙動, セメント・コンクリート論文集, No. 52, pp.74-81, 1998 16）丸嶋紀夫・黒羽健嗣・並木 哲・久保田浩：水中質量法によるフレッシ ユコンクリートの単位水量試験方法, Vol.20, No. 2, pp. 313-318, 1998

（2006年 9 月 7 日原稿受理，2006年12月 5 日採用決定） 